\title{
The Effect Of The Sharia Marketing Mix On Tourist Satisfaction After Earthquake In North Lombok Regency
}

\begin{abstract}
Abdullah Sulaiman', Anton Hindardjo²

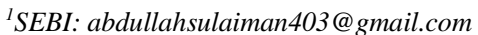

${ }^{2}$ SEBI Lecturer \& Doctoral Candidate AeU Malaysia Email

ABSTRACT. In the tourism sector, the marketing mix is impossible to separate from the satisfaction of customers or tourists. So, it is necessary to maximize the tourism market share in North Lombok Regency after the disaster, especially halal tourism by evaluating the marketing mix of sharia. Thus, it will be a strategy for tourism recovery after the disaster that occurred in North Lombok Regency. This study aims to examine the effect of Sharia Marketing Mix on Tourist Satisfaction. Data was obtained by spreading 272 questionnaires to tourists in West Lombak Regency as respondents using purposive random sampling method. While data analysis using quantitative methods with the analysis tool used is Structural Equation Modeling (SEM). The results of this study indicate that the dimensions of the marketing mix ie place and physical evidence (infrastructure) affect tourist satisfaction. The implication is that it is necessary to reform the place and physical evidence (infrastructure) in the tourist area. This is a recommendation to stakeholders in the efforts of strategies used in post-disaster recovery.
\end{abstract}

Keywords: Marketing Mix, Sharia Marketing Mix, Tourist Satisfaction, Tourism

\section{INTRODUCTION}

The halal industry trend is currently experiencing very rapid growth accompanied by consumption of halal products becoming a lifestyle for Muslimmajority countries. The halal industry consists of financial, health, fashion, cosmetics, food and tourism institutions (Indonesian Ministry of Tourism, 2015). According to UNWTO (2014), one of the industries that has grown significantly is halal tourism or better known as Muslim Friendly Tourism (MFT). The halal industry is developing with rapid growth in the global market. This growth makes the halal tourism industry in great demand by many countries, both those belonging to the OIC (Organization of Islamic Corporation) and non OIC countries. These countries have made modifications to the tourism industry segmentation in accordance with the segmentation of the development of society and the needs of tourists in a variety of services. This effort is carried out in order to expand market share, especially in the halal tourism sector so as to be able to provide the needs of global Muslim tourists.

According to COMCEC (2016), Muslim Friendly Tourism (MFT) is tourism whose focus is mainly on meeting the needs of Muslim tourists who do not want to compromise on basic needs. One of them is like a guarantee of a facility labeled halal certification that covers all tourist activities provided so that 
38 | Abdullah Sulaiman, Anton Hindardjo: The Effect 0f The Sharia Marketing Mix on Tourist Satisfaction After Earthquake In North Lombok Regency

it does not violate Islamic sharia. This guarantee aims to protect Muslim and non-Muslim consumers because halal guarantees have become a standard as well as a guarantee of security for a product offered to consumers.

The halal tourism industry is very potential in gaining an increase in regional income and even strengthening the country's foreign exchange, and can contribute to economic growth as an effort to stimulate employment and investment. According to data presented by the World Islamic Economic Forum Foundation (2016), it shows that the number of tourists experiences a significant increase every year. Increased income from halal tourism is expected to grow starting from USD 145 billion in 2014 to USD 200 billion in 2020. This is reinforced by the fact that among the 6.8 billion people in the world, there are 1.6 billion Muslims, with growth charts indicating the Muslim population in 2030 increased by around $26.5 \%$. This growth makes the size of the global market for halal tourism important to continue to be developed (Indonesian Ministry of Tourism, 2015). Moreover, the UNWTO Expert explained that the current trend shows that tourist visits around the world in 2018 are projected to grow at a rate of $4 \%-5 \%$ above the average projected only $3.8 \%$ from 2010 2020. (NWTO Asia Tourism Trends, Executive Summary 2018)

According to data from the Indonesian Ministry of Tourism (2015), it was explained that around 10.5 million people traveled to Indonesia in 2015, so they were able to generate around USD 12.4 billion for the economy. Of these, there are Muslim tourists reaching 1.8 million tourists or 20 percent of total foreign tourist visits in 2014. The average visitor stays for 8.5 days and spends USD 1,190 .

In 2015, the Indonesian Ministry of Tourism has launched 13 destinations that will be developed into halal tourism in Indonesia. One area that will be developed into halal tourism is Lombok, West Nusa Tenggara. This is based on irrefutable reasons because from 2015-2016 Lombok proved itself to be an international leader by getting nominations, namely as the world best halal desatination and world best halal honeymoon. Besides that, Lombok is also known as the Thousand Mosque Island, which indicates that there is a guarantee of worship facilities that are very easy to find. Coupled with the issuance of Regional Regulation No. 2 of 2016 concerning halal tourism as a manifestation of the government's sincerity in developing the halal tourism sector through the potential of tourist attractions owned consists of natural tourism, cultural tourism, historical tourism, culinary tourism and artificial tourism in accordance with the halal concept.

Based on data from the Central Statistics Agency (2017) of West Nusa Tenggara Province, the number of tourists visiting both domestic and foreign from 2009-2016 continued to increase. As illustrated in the following graph: 
Jurnal Ekonomi dan Perbankan Syariah

Vol. 7. No.1, April 2019: 37-52, ISSN (cet): 2355-1755 | ISSN (online): 2579-

6437

Graphic 1: Amount of Tourist Visits in West Nusa Tenggara

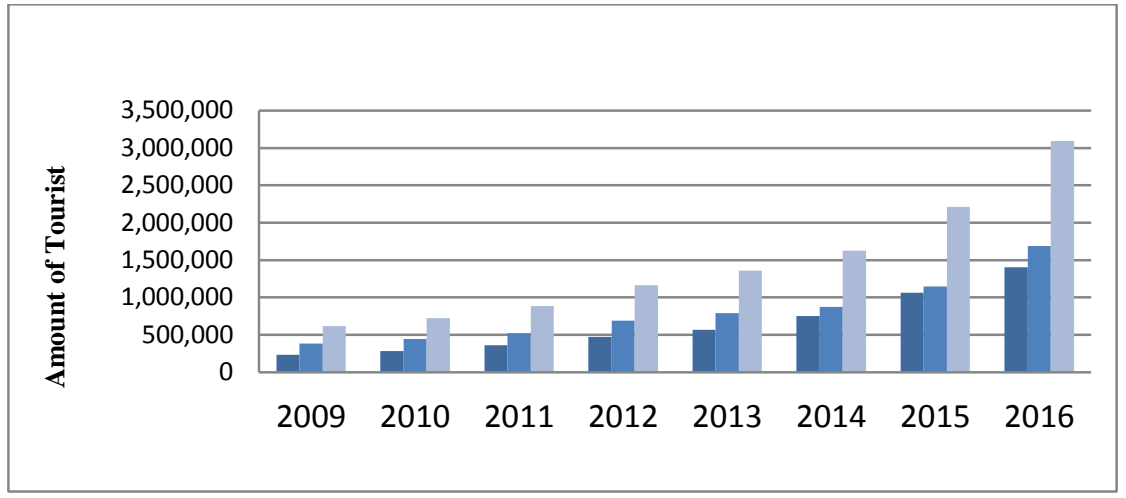

Source: Provincial Statistics Agency of West Nusa Tenggara (Processed)

Based on the graph above, the tourism sector has grown positively beginning in 2009 with the number of tourist visits reaching 619,370 tourists and in 2016 it was able to increase to 3,094,437 tourists. When viewed from the regencies and cities that are tourist destinations of West Nusa Tenggara Province, North Lombok Regency is the highest tourist destination, the number of visits from 7 regencies and 2 cities in 2014 with 503,341 tourists, followed by Mataram with 429,325 visits and the last is Bima Regency with a number of visits of 16,653 (Central Nusa Tenggara Provincial Statistics Agency, 20122014). Especially North Lombok Regency has great potential to be developed as a halal tourist destination.

However, there are main factors that become obstacles in its development, namely in the form of natural disasters. Based on a report from the Indonesian Meteorology, Climatology and Geophysics Agency, there was a natural disaster in the form of an earthquake with the strength of 7 SR on Sunday August 5th 2018 at around 6:46 p.m. WIB. The epicenter was in the area of Sambik Elen Village, Bayan District, North Lombok Regency, West Nusa Tenggara. This resulted in the North Lombok Regency being the worst affected area of the earthquake. So that natural disasters that occur can threaten the existence of government systems, social communities, organizations, the natural environment, ecosystems or other established systems including tourism. Based on data from the National Disaster Management Authority Indonesia (2018), the total temporary loss of damage and losses from the earthquake reached more than Rp. 8.8 trillion.

North Lombok Regency as a regency that has a leading sector, namely the tourism sector, also affected by natural disasters that occurred, losses in the tourism sector are estimated at 71,120 billion IDR consisting of 602 hotel or lodging units (Tourism Office of KLU, 2018). So that this certainly resulted in a decrease in the number of tourists both domestic and foreign tourists. Based on 
40 | Abdullah Sulaiman, Anton Hindardjo: The Effect Of The Sharia Marketing Mix on Tourist Satisfaction After Earthquake In North Lombok Regency

data on the number of tourist visits recorded by the North Lombok Regency Culture and Tourism Office from 2014-2017, tourist growth increased, but there was a decline after the earthquake in 2018 , as illustrated in the following graph:

\section{Graphic 2: The Number of Tourists Visiting North Lombok Regency}

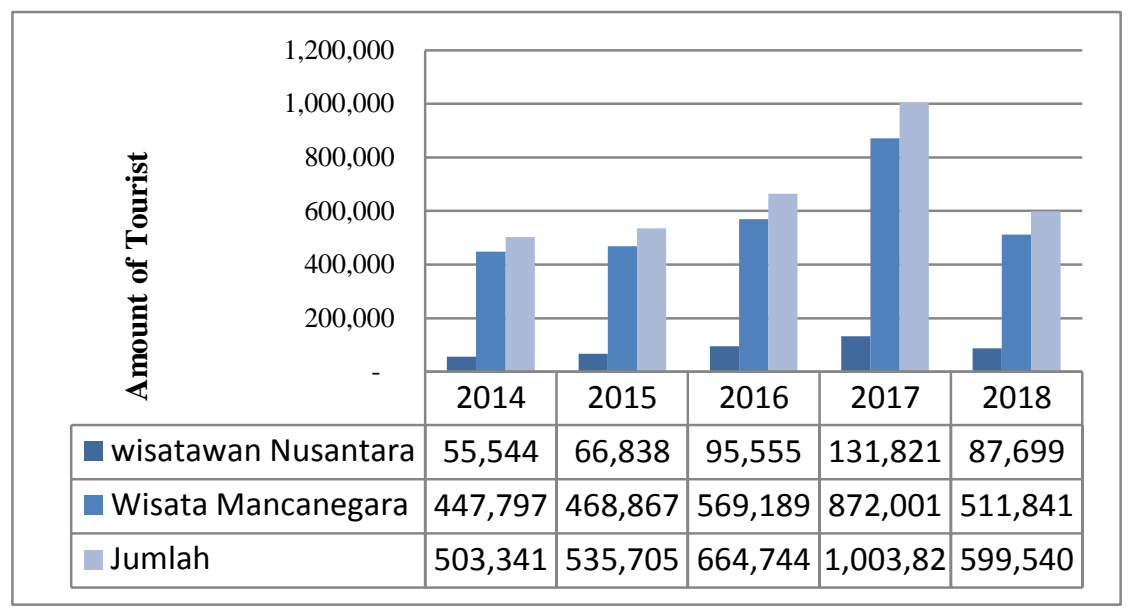

Based on the graph image above, it shows that in 2017 there was an increase in the number of tourists by $1,003,822$ people. Whereas after the earthquake in 2018 there was a significant decrease in the number of tourists by 599,540 people. so this indicates a decrease in income towards the tourism sector, especially transportation and lodging services. The impact of the disaster is disruption of tourist activities, so that this will ultimately have an impact on tourist satisfaction.

In the tourism sector, the marketing mix cannot be separated from customer or tourist satisfaction (Abdullah, 2016). To maximize the share of the tourism market in North Lombok Regency after the disaster, especially halal tourism, it is very necessary to evaluate the existing marketing mix of sharia, starting from the aspects of place, price, promotion, employees, tourism activities, to physical evidence or infrastructure (Abuznaid, 2012). Thus, after evaluating the marketing mix elements which will later become a strategy for tourism recovery after the disaster that occurred in North Lombok Regency.

In this study, researchers only took 7 of the 9 elements contained in Islamic marketing, among the elements of the sharia marketing mix, namely Products, Prices, Places, Promotions, People (employees), Processes, Physical Evidence. 


\section{LITERATURE REVIEW}

\section{MARKETING MIX AND SATISFACTION}

\section{Definition of Marketing Mix}

According to Kotler (2006) explained that the marketing mix is a marketing program that effectively integrates all elements of the marketing mix into a marketing program designed to achieve the company's marketing goals by providing value to customers.

McCarthy (2002) classifies various marketing activities into marketing elements - the mix he calls the four marketing P: Product (product), Price (price), Place (place), and Promotion (promotion). In modern marketing 4P is more developed so that it covers four more modern marketing realities; people, processes, programs, and performance (Kotler \& Keller 2012). Thus marketing mix becomes 7P, so this marketing mix has been considered to have a more significant impact on marketing for companies involved in providing services to customers (Borden, 1984)

\section{Sharia Marketing Mix}

Sharia Marketing Mix is a set of marketing elements that can be tactical controlled, and integrated by the company to produce the desired response to targeted market segmentation based on sharia principles (Abuznaid 2012).

The sharia marketing mix is:

\section{Product (Product)}

The production process in Islam is part of worship to God (Al-Faruki 1992). The main objective of the production process is to convey, improve, and fulfill basic human needs by prioritizing social and welfare approaches rather than profit maximization, so that product quality is very important to consider in Islamic business ethics (Miller, A. \& Deiss 1998)

Islamic principles explain in complex terms that production operations must be pure from beginning to end (Al-Faruki 1992). In Islam, the production decision-making process is guided by the principles of validity, purity, existence, delivery, and proper determination (Al-Misri 1991). These principles indicate that the product must:

a) Halal, does not cause disturbance in any form, does not lead to public disturbances, or immorality.

b) Products must really belong to the owner.

c) Products must be delivered

d) Goods sold must specifically mention their quantity and quality (Al Ukhuwa 1983). 
42 | Abdullah Sulaiman, Anton Hindardjo: The Effect 0f The Sharia Marketing Mix on Tourist Satisfaction After Earthquake In North Lombok Regency

\section{Price (Price)}

Islam does not look at prices solely from a business perspective but also from the interests of society. According to Abdullah and Ahmad (2010), the interests of all parties must be protected (buyers, sellers, communities, etc.). Islam insists that any personal interest must not be at the expense of the public interest. Then the price policy in Islam must:

a) Does not give customers a false impression that they are getting an offer (Shaw, 1996).

b) Prohibit getting things easily without working hard (Maisir), or receiving profits without working for it.

c) Change prices without changing product quantity or quality.

d) It is not permissible to deceive customers to obtain illegal profits

e) Price discrimination between bargaining and not bargaining to sell the same item for different prices is prohibited.

f) Prohibiting false propaganda from international marketers regarding the supply position of requests through the media.

g) Having price controls and manipulation to meet market needs as a result of scarcity of natural supplies is not prohibited.

h) Hoarding any product is prohibited in Islam.

\section{Place (Distribution / Marketing)}

Hassan, Chachi, and Abdul Latif (2008) describe the principles of marketing in Islam by combining maximization of values and principles of justice for a wider scope of public welfare. The main purpose of marketing is to create value and improve living standards by providing ethically satisfying products and services (Saeed, Ahmed, and Mukhtar 2001).

In the case of distribution, some unethical practices that must be avoided are related to distribution channels, namely:
a) Manipulate product availability with the aim of exploiting customers.
b) Forcing customers in the distribution channel.
c) Exert undue pressure on the retailer's choice to handle the product.
d) Packaging design without the right security and security for the product
e) Inappropriate product packaging
f) Transport dangerous and toxic products through public facilities
g) Distributing illegitimate products along with halal products (Hassan 2008). 
Jurnal Ekonomi dan Perbankan Syariah

Vol. 7. No.1, April 2019: 37-52, ISSN (cet): 2355-1755 | ISSN (online): 2579-

6437

| 43

\section{Promotion (Promotion)}

In Islamic business ethics, every promotion is prohibited from using female stereotypes in advertising, excessive use of fantasy, use of language and suggestive behavior, and use of women as objects to attract and attract customers (Erffmeyer et al. 1993; Beekun, 1981; Razzouk, 1993). This indicates that in Islamic business ethics all forms of manipulative promotions are prohibited to be carried out such as:

a) Give a false impression in any form to promote the product.

b) Promotions that contain content of fraud, betrayal, theft or injustice.

c) Hiding product errors and defects.

d) Promotion with the use of sexual attraction or exploiting women in advertisements for fishing and attracting customers.

e) Use language and behavior that is suggestive and uses obscene advertisements to promote products / services.

\section{People (Employees)}

Employees are an important part of the marketing process service delivery process. Employees must be patient, honest, fair and responsible. employees must have an attitude of responsibility in marketing not to use any form of coercion to do something without consumer consent, and must have an awareness of intellectual integrity in all circumstances relating to customer service (Abuznaid, 2012).

In Islam, it is explained that employees or marketers must show a sense of responsibility in four categories: responsibility towards God, responsibility to society, respecting the welfare and responsibility of marketers themselves to the environment (Saeed, Ahmed, and Mukhtar 2001). So that it will show employee integrity professionally and have implications for consumer satisfaction.

\section{Process (process)}

Process elements include procedures, mechanisms, and flow of activities. The process also means how the product will reach the end user, that is the consumer. An important element of this marketing mix focuses on creating customer satisfaction. The things to do are:

a) Paying attention to intellectual integrity and a higher level of consumer awareness without having to use any form of coercion.

b) Marketers must have some basic values, such as honesty, responsibility, fairness and respect.

c) They must separate between business demands and personal needs and the desire to achieve ethical marketing decisions. 
44 | Abdullah Sulaiman, Anton Hindardjo: The Effect 0f The Sharia Marketing Mix on Tourist Satisfaction After Earthquake In North Lombok Regency

d) Avoid all forms of fraudulent transactions and exploitation of natural and human resources. (Abuznaid 2012).

\section{Physical Evidence (Physical Evidence)}

Physical evidence is an important element of the service mix that allows consumers to provide an assessment of the company or organization being run. This makes consumers often rely on physical evidence contained in each service provided to assist in conducting evaluations.

According to Abuznaid (2012) physical evidence can be divided into three categories:

a) Exterior facilities include exterior design, nameplate, parking, landscape, and surrounding environment, such as building facilities on a mountain site, overlooking the lake. In some Muslim countries such as banks, shopping centers take the form of Islamic architecture.

b) Interior facilities include elements such as interior design, equipment used to serve customers directly or used to run a business, nameplate, air quality and temperature (Hoffman and Bateson, 2006). There are Al-Qur'an, and Hadith and Arabic wisdom and sayings posted on the wall in many businesses. There are prayer rugs in worship facilities or mosques so that employees and consumers can worship.

c) Other tangibles (concrete evidence) that are part of the company's physical evidence, including items such as business cards, stationery, billing statements, reports, employee appearance, uniforms and brochures (Bitner, 1992).

\section{Promise}

Fulfilling promises given is just as important as achieving customer satisfaction, maintaining a customer base and long-term profitability (Abuznaid 2012). It must be stressed that promises must be given to each other and maintained. Marketers should not give false promises. As God has commanded believers to respect and keep promises. The Qur'an states "O you who believe! fulfill your obligations "(QS. Maida 5: 1) and Say" O you who believe! Why did you say what you did not do? The most hated thing is with God that you say what you don't do (Quran, 61: 2,3) and declare, "O you who believe! Fear Allah and be with those who are right in words and deeds" (Quran, $9: 119$ ). The importance of maintaining promises has been emphasized in the Sunnah. Prophet Muhammad (PBUH) said in the Hadith: "the three signs of blasphemy are: lying, not keeping promises and not being trusted". From an Islamic perspective, any promises given to customers must be maintained and respected.

\section{Patience}

Patience is another element of the Islamic marketing mix. So this element is very important in the service industry, because Islam urges people to be patient in dealing with customers (Abuznaid 2012). Patience is a key characteristic of good communication. Because of the importance of this, God gives a chapter in the Quran for patience (shabireen). 
Jurnal Ekonomi dan Perbankan Syariah

Vol. 7. No.1, April 2019: 37-52, ISSN (cet): 2355-1755 | ISSN (online): 2579-

6437

45

\section{Customer satisfaction}

According to Kotler (2010) that customer satisfaction is a social and managerial process that provides individuals and groups with the things they need and want by creating, offering and exchanging value products So that the success of an organization or company is influenced by the level of customer satisfaction at their request. This is a big challenge for every organization to achieve the highest level of customer satisfaction.

\section{TOURISM}

\section{Understanding Tourism}

Tourism is a variety of tourism activities that are supported by various facilities and services provided by the community, businessmen, government, and local government (Presidential Regulation number 63 of 2014, 2014)

Meanwhile, according to Sugiama (2011) Tourism is a series of activities, and the provision of services both for the needs of tourist attractions, transportation, accommodation, and other services, to meet the travel needs of tourists.

From some of the meanings described above, a definition of tourism can be taken, namely a series of travel activities (tourism) that have facilities and services provided by the community, businessmen, government, and local governments to meet the needs of tourists.

\section{Tourism Criteria}

According to Yoeti (1999) tourism must meet four criteria, namely:

1) The trip is carried out from one place to another, the trip is carried out outside the place where the person lives.

2) The purpose of the trip is carried out solely for fun, without earning a living either in the country or city or the tourist attractions visited.

3) The money spent by tourists is taken from their home countries, where they can stay or stay, and not be obtained from the results of the business during the tour, and

4) travel is carried out at least 24 hours or more.

\section{HALAL TOURISM}

\section{The Comparison}

The fatwa of the National Sharia Council of the Indonesian Ulema Council No.108 (2016) explains that sharia tourism is a variety of tourism activities and is supported by various facilities and services provided by the community, businessmen, government and local governments in accordance with sharia principles. 
46 | Abdullah Sulaiman, Anton Hindardjo: The Effect 0f The Sharia Marketing Mix on Tourist Satisfaction After Earthquake In North Lombok Regency

Halal tourism has a broader meaning than conventional tourism or religious tourism, this can be seen from several aspects which will be explained in the following table:

Table 1.1 Comparison between Conventional Tourism, Religious Tourism, and Halal Tourism

\begin{tabular}{|c|c|c|c|}
\hline Attributes & $\begin{array}{c}\text { Conventional } \\
\text { Tourism }\end{array}$ & $\begin{array}{l}\text { Religious } \\
\text { Tourism }\end{array}$ & $\begin{array}{c}\text { Halal } \\
\text { Toursim }\end{array}$ \\
\hline Object & $\begin{array}{l}\text { Nature, culture, } \\
\text { heritage, culinary }\end{array}$ & $\begin{array}{c}\text { Places of worship, } \\
\text { heritage }\end{array}$ & All \\
\hline Purpose & Entertaining & $\begin{array}{l}\text { Enhancing } \\
\text { spirituality }\end{array}$ & $\begin{array}{c}\text { Enhancing } \\
\text { spirituality by } \\
\text { entertaining }\end{array}$ \\
\hline Target & $\begin{array}{c}\text { Touching } \\
\text { satisfaction and } \\
\text { pleasure with } \\
\text { dimensions of lust, } \\
\text { solely for holidays. }\end{array}$ & $\begin{array}{l}\text { Spiritual aspects } \\
\text { that can calm the } \\
\text { soul. To seek } \\
\text { inner calm }\end{array}$ & $\begin{array}{c}\text { Fulfill your } \\
\text { desires and } \\
\text { pleasures and } \\
\text { foster diverse } \\
\text { awareness }\end{array}$ \\
\hline Guide & $\begin{array}{c}\text { Understand and } \\
\text { master information } \\
\text { so that it can attract } \\
\text { tourists to } \\
\text { attractions }\end{array}$ & & $\begin{array}{l}\text { Make tourists } \\
\text { interested in } \\
\text { objects while } \\
\text { raising } \\
\text { religious spirit }\end{array}$ \\
\hline $\begin{array}{l}\text { Worship } \\
\text { facilities }\end{array}$ & Just a complement & $\begin{array}{c}\text { Just a } \\
\text { complement }\end{array}$ & $\begin{array}{l}\text { Being a part } \\
\text { that blends } \\
\text { with the } \\
\text { tourist } \\
\text { attraction, the } \\
\text { ritual of } \\
\text { worship } \\
\text { becomes part } \\
\text { of the }\end{array}$ \\
\hline
\end{tabular}


entertainment

package

\begin{tabular}{cccc}
\hline Culinary & Common & Common & $\begin{array}{c}\text { Halal } \\
\text { specifications }\end{array}$ \\
\hline $\begin{array}{c}\text { Relations } \\
\text { with the }\end{array}$ & Complementary & Complementary & $\begin{array}{c}\text { Integrated and } \\
\text { and only for }\end{array}$ \\
$\begin{array}{c}\text { and only for } \\
\text { interaction } \\
\text { the tourist }\end{array}$ & & material benefits & based on \\
environment & & & sharia \\
Travel & Every time & Certain time & Pay attention \\
agenda & & & to time
\end{tabular}

\section{Characteristics of Halal Tourism}

According to Chukaew (2015) explained that there are eight standards of halal tourism measurement in terms of administration and management for all tourists, which can be a distinctive characteristic, namely services to tourists must be in accordance with Muslim principles as a whole, guides and staff must have discipline and respecting Islamic principles, regulating all activities so that they do not conflict with Islamic principles, buildings must comply with Islamic principles, restaurants must follow international standards of halal services, transportation services must have security protection systems, there are places provided for all tourists Muslims carry out religious activities, travel to places that do not conflict with Islamic principles.

From the characteristics of halal tourism described by Chukaew (2015), there are four important aspects that must be considered to support halal tourism, namely location, transportation, consumption, and hotels based on sharia principles.

From the description of the literature review, we make a conceptual framework. The conceptual framework of this research is as follows. 
48 | Abdullah Sulaiman, Anton Hindardjo: The Effect Of The Sharia Marketing Mix on Tourist Satisfaction After Earthquake In North Lombok Regency

Figure 1: Conceptual Framework

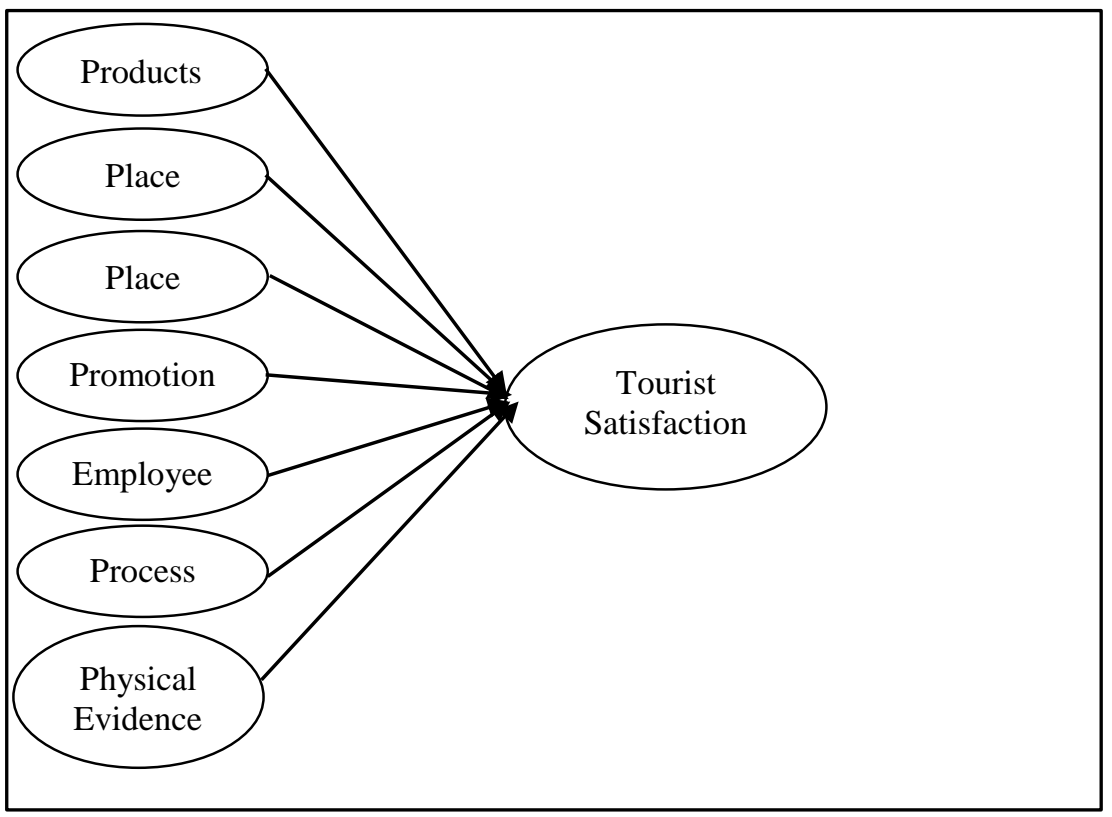

\section{METHODOLOGY}

This study uses a quantitative approach. This research method aims to find out and analyze how the relationship between the influence of the Islamic marketing mix on tourist satisfaction after the earthquake in North Lombok Regency. In this study to obtain primary data was carried out by distributing questionnaires directly to tourists who had visited North Lombok Regency after the disaster. Data was obtained by distributing 272 questionnaires to tourists as respondents in North Lombok Regency using purposive random sampling method.

In this study using a Likert scale. The Likert scale is a scale based on the sum of the attitudes of respondents in responding to statements relating to indicators of a concept or variable being measured.

The data analysis technique in this study was carried out using the SEM (Structural Equation Modeling) model with the PLS (Partial Least Square) approach, where this model is a collection of statistical techniques that allow testing of a series of relatively complicated and simultaneous relationships. 
Jurnal Ekonomi dan Perbankan Syariah

Vol. 7. No.1, April 2019: 37-52, ISSN (cet): 2355-1755 | ISSN (online): 2579-

6437

| 49

\section{RESULTS \& DISCUSSION}

\section{STATISTICAL RESULTS}

Based on the statistical results, there are the parameter results of tstatistics. A significant relationship if the t-statistic value passes the value of 1.96 or the P-Value value below 0.05. The following is a table of results of the tStatistic and P-Value values:

Tabel 1.2. t-Statistics and P-Value Results

\begin{tabular}{lcc}
\hline & t-Statistics & P Value \\
\hline Product $\rightarrow$ Tourist Satisfaction & 0.188 & 0.851 \\
\hline Price $\rightarrow$ Tourist Satisfaction & 1.844 & 0.066 \\
\hline Place $\rightarrow$ Tourist Satisfaction & $2.553^{*}$ & 0.011 \\
\hline Promotion $\rightarrow$ Tourist Satisfaction & 1.321 & 0.187 \\
\hline Employee $\rightarrow$ Tourist Satisfaction & 0.061 & 0.951 \\
\hline Process $\rightarrow$ Tourist Satisfaction & 0.736 & 0.426 \\
\hline Physical Evidence $\rightarrow$ Tourist Satisfaction & $3.771^{*}$ & 0.000
\end{tabular}

Based on the table above, there are only two elements of the Islamic marketing mix that affect tourist satisfaction, namely:

\section{The Influence of Places on Customer Satisfaction}

Based on the results of statistical calculations, it can be concluded that the place construct has a positive and insignificant effect on the construct of Customer Satisfaction directly. This can be seen from the value of T-Statistics which is smaller than 1960 which is 2,553. This shows that places tend to influence customer satisfaction.

\section{Effect of Physical Evidence on Customer Satisfaction}

Based on the results of statistical calculations, it can be concluded that the construct of Physical Evidence has a significant positive effect on the construct of Customer Satisfaction directly. This can be seen from the value of T-Statistics which is greater than 1,960 which is equal to 3,771. Thus, the H7 hypoesis in this study was accepted. This shows that Physical Evidence tends to influence Customer Satisfaction. 
50 | Abdullah Sulaiman, Anton Hindardjo: The Effect 0f The Sharia Marketing Mix on Tourist Satisfaction After Earthquake In North Lombok Regency

\section{DISCUSSION}

The results of the study show the main needs of Muslim tourists, namely in the Islamic marketing mix is to provide facilities. Average Muslim tourists consider the ease of worship activities. Religious facilities such as mosques, ablution places play an important role in tourist satisfaction. Besides public facilities and infrastructure such as ports and airports that connect to tourist destinations also affect the satisfaction of Muslim tourists. In addition, the most important thing about existing tourist attractions is that they are not allowed to exploit the environment, thus damaging existing ecosystems. The next most important thing is that tourist attractions are expected to be easily accessible to Muslim tourists. In the end, security and order in tourist attractions also determine tourist satisfaction so that Muslim tourists can do tourism activities well.

Based on the results of the study also, the Islamic marketing mix must consider not allowed gambling and bars that provide alcoholic drinks and attractions that are not in accordance with Islamic sharia. Furthermore, it is necessary to have the Holy Qur'an and Hadith books on tourist attractions in order to study and remind the glory of Allah (Abuznaid, 2012)

\section{CONCLUSION}

From the results of the analysis of influences between latent variables, it can be concluded that there are only two marketing mix variables that influence tourist satisfaction after the earthquake that occurred in North Lombok district, namely Place and Physical Evidence or Infrastructure. So that this becomes a recommendation to stakeholders, especially the government and business actors in halal tourism recovery efforts, to focus on revamping Tourism Sites and Physical Evidence (Infrastructure) as the main concern that must be done to support the recovery of halal tourism after the disaster.

For future research, this research can be applied in other halal tourist locations. In addition, a more sophisticated research model with more sample sizes is needed.

\section{BIBLIOGRAPHY}

Abdullah, Faris, Thaer F Abdullah, and Mahir F Abdullah. (2016). "Effects of Marketing Mix on Customer Satisfaction : Empirical Study on Tourism Industry in Malaysia." 2: 357-60.

Abdullah, Kalthom, and Mohd Ismail Ahmad. (2010). "Compliance to Islamic Marketing Practices among Businesses in Malaysia." Journal of Islamic Marketing 1(3): 286-97.

Abuznaid, S. (2012). “An - Najah Univ. J. Res. (Humanities). Vol. 26(6), 2012.” Humanities 26(6): 1473-1503.

Abuznaid, Samir. (2006). "Islam and Management: What Can Be Learned?" 14. 
Jurnal Ekonomi dan Perbankan Syariah

Vol. 7. No.1, April 2019: 37-52, ISSN (cet): 2355-1755 | ISSN (online): 2579-

6437

\section{| 51}

Al-Faruki, Ismail Raji. 1992. "Its Implication for Thought and Life."

Al-Misri, Ahmad Ibn Naqub. 1991. "The Reminiscences of the Traveler: A Classical Manual of Islamic Sacred Law."

Arifin, Johar. 2015. "WAWASAN AL-QURAN DAN SUNNAH TENTANG PARIWISATA Oleh : Johar Arifin." 4(2): 147-66.

Borden, N.H. 1984. "The Concept of the Marketing Mix." Journal of Advertising Research Vol.4: 2-7.

Chookaew, Sureerat, Jirapa Charatarawat, Pingpis Sriprasert, and Sudarat Nimpaya. 2015. "Increasing Halal Tourism Potential at Andaman Gulf in Thailand for Muslim Country." 3(7).

COMCEC. 2016. Muslim Friendly Tourism: Understanding the Demand and Supply Sides In the OIC Member Countries. No Title.

Cooke, EF. Rayburn, JM. \& Abercrombie, CL. 1992. "“The History of Marketing Thought as Reflected in the Definitions of Marketing'. Theory and Practice." journal of Marketing: 10-20.

Dinas Kebudayaan dan Pariwisata kabupaten Lombok Utara. 2018. Data Kerusakan Pariswisata_Revisi.

Farrel, T. A. Hall, T.E. \& White, D.D. . ". 2001. “'Wilderness Campers. Perception and Evaluation of Campsite Impacts'." Journal of Leisure Research.: 229-50.

Ghozali, Imam. 2006. Structural Equation Modeling, Metode Alternatif Dengan Partial Least Square. 2nd ed. Semarang: Universitas Diponegoro.

Gro, Christian. 1999. "Marketing as Promise Management : Regaining Customer Management for Marketing."

H. Oka A. Yoeti. 1999. Industri Pariwisata Dan Peluang Kesempatan Kerja. Jakarta.

Hamzah, M. \& Yudiana, Yi. 2015. "No Title." Analisis komparatif potensi industri halal dalam wisata syariah dengan konvensional.

Hassan, Abul, Abdelkader Chachi, and Salma AbdulLatiff. 2008. "Islamic Marketing Ethics and Its Impact on Customer Satisfaction in the Islamic Banking Industry." Journal of King Abdulaziz UniversityIslamic Economics 21(1):27-46. http://prod.kau.edu.sa/centers/spc/jkau/Data/Review_Artical.aspx?No $=2606$.

Indonesia, Dewan syariah Nasional Majlis Ulama. 2016. "Fatwa DEWAN SYARIAH NASIONAL-MAJELIS ULAMA INDONESIA 108/DsnMui/X/2016.” (19).

Kasriel, Daphne. 2008. "Spotlighting Europe's Muslim Consumers. UK: London."

Kearney, A. T. 2006. "Addressing the Muslim Market." : 1-19. http://imaratconsultants.com/wpcontent/uploads/2012/10/Addressing-Muslim-Market.pdf.

KEMENPAR. 2015.

Kotler, P. \& Keller, K. 2012. Marketing Management. 14th Global. Pearson Ed. 
52 | Abdullah Sulaiman, Anton Hindardjo: The Effect 0f The Sharia Marketing Mix on Tourist Satisfaction After Earthquake In North Lombok Regency

Kotler P, Armstrong G. 2006. Principle of Marketing.

Kotler P, Armstrong G. 2010. Principles of Marketing.

Miller, A. \& Deiss, G.G. 1998. "Strategic Management." The Consequences of Misunderstanding disaster.

Muljadi, A.J. 2011. Kepariwisataan Dan Perjalanan.

NTB, BPS. 2017. Jumlah Kunjungan Wisatawan NTB.

"NWTO/GTERC Asia Tourism Trends, Executive Summary." 2018. https://www.e-unwto.org/doi/pdf/10.18111/9789284420056.

Paul Sergius Koku. 2011. "Natural Market Segments: Religion and Identity the Case of 'Zongos' in Ghana."

Peraturan Daerah, Provinsi Nusa, and Tenggara Barat. 2016. "Lembaran Daerah Provinsi Nusa Tenggara Barat." : 1-51.

peraturan presiden. 2014. 2025 Peraturan Presiden Republik Indonesia No. 63 Tahun 2014.

Saeed, Mohammad, Zafar U. Ahmed, and Syeda Masooda Mukhtar. 2001. "International Marketing Ethics from an Islamic Perspective: A ValueMaximization Approach.” Journal of Business Ethics 32(2): 127-42.

Sugiama, A. Gima. 2011. "ANALISIS DISKRIMINAN PERSEPSI WISATAWAN TERHADAP KUALITAS KOMPONEN KEPARIWISATAAN DI KAWASANA WISATA AGRO." 2(pariwisata): 1-9.

Sugiyono. 2010. Metode Penelitian Pendidikan Pendekatan Kuantitatif, Kualitatif, Dan R\&D. Bandung.

2011. Metode Penelitian Kuantitatif, Kualitatif Dan R\&D. Bandung: Afabeta.

2013. Metode Penelitian Manajemen. 3rd ed. ed. Setiyawami. Bandung: Alfabeta.

Al Ukhuwa, Dia'al-Din Muhammad Ibn. 1983. "The Ma'alim Al Qqurab Fi Ahkam Al-Hisbah."

UNWTO. 2014.

"World Islamic Economic Forum Foundation." 2016.

Zamani-Farahani, H., \& Henderson, J. C. 2009. "No Title.” Islamic tourism and managing tourism development in Islamic societies: The cases of Iran and Saudi Arabia. 